\title{
Strategi Peladang Berpindah di Routa Dalam Rangka Menguatkan Klaim Hak Atas Tanah Bekas Areal Perladangan Berpindah di Masa Lalu
}

\author{
Sarlan Adijaya \\ Universitas Haluoleo \\ rambuwawi@gmail.com
}

\begin{abstract}
Claims of rights to land formerly shifting cultivation areas in the past, as referred to by the terms orawu, anahoma, laliwata and osambu are now increasingly ineffective - one of which is because the former shifting cultivation area has been abandoned for a long time where the trees have grown as usual, until hardly leaving the slightest sign of former swidden cultivation areas. As a result, lands in the former shifting cultivation areas in the past are now being taken over and controlled by other parties.
\end{abstract}

This research, which lasted for six months, was conducted in Routa District, Konawe Regency, Southeast Sulawesi Province, considering that in this area a new phenomenon has developed in which land formerly cultivated areas in the past was re-opened by their descendants of current shifting cultivators in order to strengthen land rights claims. There are .... informants participated in this study, including shifting cultivators and descendants of shifting cultivators, government officials, and local law enforcers. Data collection techniques were carried out through interviews and observations.

The study shows that the current strategy of the descendants of shifting cultivators in Routa is to re-open their parents' former shifting cultivation areas - this strategy is increasingly emphasized through planting growing crops, creating boundaries and legalizing land rights with both SKT and SHM. These strategies have proven to be quite successful in overcoming the encroachment of former shifting cultivation areas as well as providing new economic bases for shifting cultivators in the form of land and gardens.

Keywords: Strategy, land, cultivator, cultivated area, shifting cultivation, and tenure.

\section{Pendahuluan}

Klaim hak atas tanah bekas areal perladangan berpindah dimasa lalu yang memiliki beragam istilah, yakni orawu, anahoma, laliwata dan osambu, saat ini semakin tidak efektif lagi karena beragam hal. Pertama, bekas areal perladangan berpindah tersebut telah cukup lama ditinggalkan dimana pepohonan sudah tumbuh seperti sediakala, hingga hampir tidak menyisakan lagi sedikit pun tanda sebagai bekas areal perladangan berpindah. Kedua, tidak adanya tanaman tumbuh tertentu yang menonjol di atas tanah bekas areal perladangan berpindah yang berfungsi sebagai penanda. Ketiga, tidak nampak adanya penguasaan fisik secara nyata oleh anak keturunan peladang berpindah terhadap bekas areal perladangan berpindah tersebut. Akibatnya, tanah-tanah pada bekas areal perladangan berpindah di masa lalu, saat ini banyak diserobot dan dikuasai oleh pihakpihak lain, yaitu pengusaha kayu, pengusaha perkebunan kelapa sawit, pengusaha pertambangan nikel, migran dari Selatan dan orang-orang kaya baru. Situasi ini menyebabkan anak keturunan peladang berpindah kehilangan akses/kontrol atas tanah-tanah bekas areal perladangan 
berpindah orang tua mereka dimasa lalu serta secara langsung pula membatasi kesempatan mereka untuk mengembangkan praktek perladangan berpindah di atas tanah bekas areal perladangan berpindah tersebut.

Berkenaan dengan hal-hal tersebut di atas, maka artikel ini ditujukan untuk mengeksplorasi strategi-strategi yang dilakukan oleh anak keturunan peladang berpindah di Routa dalam rangka menguatkan kembali klaim hak atas tanah bekas areal perladangan berpindah orang tua mereka di masa lalu serta sejauh mana strategi-strategi tersebut dapat berjalan efektif.

Adaptasi merupakan konsep sentral dalam studi ekologi karena ini adalah proses dimana hubungan organisme/lingkungan yang menguntungkan terbentuk (Hardesty 1941:21). Penekanan Hardesty pada adaptasi sebagai konsep sentral dalam kajian ekologi, meliputi pula kajian antropologi ekologi. Antropologi ekologi sebagai cabang ilmu antropologi yang melibatkan diri dalam studistudi lingkungan ekologis atau menjadikan lingkungan sebagai latar belakang kajiannya (Hardesty 1941:1; Steward 1976:43-57; Moran 1979:4; Ellen 1982:1; Rambo 1983:1; Johnston 2010:3).

Bennet (1976:246) menganggap bahwa adaptasi adalah kapasitas manusia untuk melakukan self-objectification, belajar dan mengantisipasi. Adaptasi terhadap lingkungan dibentuk dari tindakan yang berulang-ulang sebagai proses penyesuaian terhadap lingkungan tersebut. Bennet menekankan bahwa adaptasi bukan hanya persoalan bagaimana mendapatkan makanan dari suatu kawasan tertentu, tetapi juga mencakup persoalan transformasi sumberdaya lokal dengan mengikuti model standar konsumsi manusia yang umum serta biaya dan harga atau mode-mode produksi di tingkat nasional.

Selanjutnya Bennet (1969:11-14) mengindikasikan bahwa terdapat 3 jenis adaptasi yang berbeda satu dengan lainnya, yaitu adaptive behavior (perilaku adaptif), adaptive strategies (siasat-siasat adaptif), dan adaptive processes (proses-proses adaptif). Perilaku adaptif merupakan "mekanisme koping atau cara menghadapi orang dan sumber daya untuk mencapai tujuan dan menyelesaikan masalah"; strategi adaptif adalah "pola yang dibentuk oleh banyak penyesuaian terpisah yang dilakukan orangorang untuk mendapatkan dan menggunakan sumber daya dan untuk memecahkan masalah langsung yang dihadapi mereka"; sedangkan proses adaptif merupakan "perubahan yang diperkenalkan dalam periode waktu yang relatif lama dengan penggunaan berulang dari strategi tersebut".

Lebih lanjut Bennet (1969: 11-15) mengemukakan beberapa poin penting dari adaptasi, yaitu: siasat-siasat adaptif tersebut berada pada tingkat yang disadari oleh para pelaku; siasat-siasat tersebut dirumuskan dalam bentuk pengetahuan maupun tindakan; proses-proses adaptif adalah pernyataan, formulasi dari pengamat atau/peneliti, dan; adaptif atau tidak adaptif-nya suatu perilaku ditentukan apakah perilaku tersebut berkenaan dengan pencapaian tujuan atau penyelesaian masalah, seperti mengatasi keterbatasan atau kelangkaan sumberdaya guna mencapai tujuan-tujuan tertentu atau untuk mewujudkan keinginan-keinginan yang diharapkan.

Berdasarkan uraian-uraian di atas, maka tindakan anak keturunan peladang berpindah yang kembali membuka bekas areal perladangan berpindah orang tua mereka di masa lalu adalah suatu strategi adaptasi terhadap praktek penguasaan tanah bekas areal perladangan berpindah yang dilakukan oleh pengusaha kayu, pengusaha perkebunan, pengusaha pertambangan, migran dan orangorang kaya baru di Routa.

Perladangan berpindah, pertanian gilir balik atau pertanian tebang bakar 
merupakan suatu sistem pertanian dalam kawasan hutan yang kegiatan intinya meliputi penebangan, pembakaran dan penanaman, dengan istilah yang beragam di berbagai belahan dunia. Rambo (1983:8), misalnya, mengemukakan bahwa "sistem pertanian berpindah (swidden agriculture) adalah sistem di mana petani menebang sebidang tanah di hutan, membiarkan vegetasi mengering dan kemudian membakarnya sebelum menanam tanaman". Sementara Seavoy (1973:22) mendefinisikan "sistem perladangan berpindah (shifting cultivation) umumnya didefinisikan sebagai menebang pohon dan kemudian mengolah tanah ini selama satu tahun atau lebih sebelum meninggalkannya untuk kepentingan tambalan lain". Jika Rambo menekankan pada adanya praktek penebangan, pengeringan, pembakaran dan penanaman dari perladangan berpindah, maka Seavoy lebih menitikberatkan pada praktek penebangan pepohonan dan pengolahan tanah untuk beberapa tahun sebelum kemudian ditinggalkan.

Pada suku Tolaki, Taridala dan Adijaya (2002:27), secara lebih rinci mengemukakan bahwa perladangan berpindah (monda'u) adalah suatu bentuk usaha perladangan yang dilakukan dengan cara menebang pepohonan dan membakarnya dengan tahapan, yang diawali dengan monggiikii ando'olo (pemilihan lokasi perladangan); mohoto o wuta (upacara pra monda'u); mosalei (menebang pepohonan kecil, menebas akar-akaran, dan lain-lain); monduehi (menebang pepohonan besar); humunu (membakar); mo'enggai (membersihkan sisa-sisa pembakaran); motasu (menanam padi); mosaira dan mete'ia (membersihkan rerumputan dan menjaga tanaman); mosowi (panen); dan diakhiri dengan molonggo (memasukkan ke dalam lumbung).

Mekanisme penguasaan tanah berkelindan dengan konsep hak menguasai atas tanah, yang meliputi hak menguasai negara dan hak menguasai masyarakat. Konsep hak menguasai negara bersumber pada teori domain atau domain theory yang menyatakan bahwa semua tanah adalah milik raja atau pemerintah (Suhendar dan Kasim 1996:10). Teori inilah yang kemudian menjadi dasar dibuatnya undang-undang pertanahan atau agrariche wet yang salah satu pasalnya menyatakan, bahwa "semua tanah yang tidak terbukti bahwa atas tanah itu tidak ada hak milik mutlak (eigendom) adalah domein negara (Harsono dkk. 1996:14).

Kendati tidak persis sama dengan agrariche wet tersebut di atas, UndangUndang Pokok Agraria Nomor 5 Tahun 1960 (selanjutnya disebut UU Pokok Agraria) memberikan kekuasaan yang besar kepada negara untuk mengendalikan urusan pertanahan. Pasal 2 (ayat 2) memberikan wewenang kepada negara untuk: 1) mengatur dan menyelengarakan peruntukan, penggunaan, persediaan dan pemeliharaan bumi, air dan ruang angkasa; 2) menentukan dan mengatur hubungan-hubungan hukum antara orang-orang dengan bumi, air dan ruang angkasa dengan perbuatan-perbuatan hukum yang mengenai bumi, air dan ruang angkasa, dan; 3) menentukan dan mengatur hubunganhubungan hukum dan perbuatan-perbuatan hukum yang mengenai bumi, air dan ruang angkasa.

Sejalan dengan UU Pokok Agraria, Undang-Undang Nomor 41 Tahun 1999 tentang Kehutanan (selanjutnya disebut UU Kehutanan, pasal 4) menyebutkan bahwa: 1) Semua hutan di dalam wilayah Republik Indonesia, termasuk kekayaan alam yang terkandung di dalamnya dikuasai oleh negara untuk sebesar-besar kemakmuran rakyat; 2) Penguasaan hutan oleh negara sebagaimana dimaksud pada ayat (1) memberi wewenang kepada Pemerintah untuk: a. mengatur dan mengurus segala sesuatu yang berkaitan dengan hutan, kawasan hutan, dan hasil hutan; b. menetapkan status wilayah tertentu sebagai 
kawasan hutan atau kawasan hutan sebagai bukan kawasan hutan; dan c. mengatur dan menetapkan hubungan-hubungan hukum antara orang dengan hutan, serta mengatur perbuatan-perbuatan hukum mengenai kehutanan; 3) penguasaan hutan oleh negara tetap memperhatikan hak masyarakat hukum adat, sepanjang kenyataannya masih ada dan diakui keberadaannya, serta tidak bertentangan dengan kepentingan nasional.

Sementara itu hak menguasai masyarakat atas tanah bersumber pada hukum adat yang diistilahkan eigendomsrecht (hak eigendom), communaal bezitsrecht (hak komunal), beschikkingsrecht (hak pertuanan) atau beschikken (hak untuk menguasai mutlak). Menurut perspektif hukum adat, tanah sejatinya adalah milik komunal, tetapi dapat menjadi milik perseorangan manakala terjadi hubungan timbal balik yang intensif antara seseorang dengan suatu bidang tanah. Semakin intensif seseorang mengolah suatu bidang tanah, maka semakin kuat pula haknya atas tanah tersebut, dan pada saat yang sama semakin hilanglah pula hak komunal atas bidang tanah itu. Sebaliknya, jika seseorang tidak lagi berhubungan intensif dengan suatu bidang tanah, maka hak komunal dengan sendirinya menjadi pulih kembali (Ter Haar 2001:49-51).

Tidak ada tanah di dunia ini betapapun jauhnya di padang gurun yang tidak diklaim oleh suatu negeri (Kroesen 1874; Beckmann dan Beckmann 2008:8). Pernyataan ini menunjukkan bahwa tidak pernah ada tanah yang benar-benar kosong dari penguasaan atau kepemilikan, tetapi yang ada hanyalah kosong dari pemukim atau sedang tidak dimanfaatkan. Ini mengkonfirmasi kasus kembalinya Orang Pondoa dan Orang Mopute

\footnotetext{
${ }^{1}$ Pada masyarakat Tolaki sendiri istilah-istilah tanah adat atau hak adat atas tanah meliputi: anahoma/anasepu (belukar bekas perladangan), o galu (tanah persawahan), o epe (lokasi tanaman sagu), walaka (areal tempat melepaskan kerbau),
}

membuka areal perladangan berpindah dalam wilayah IUP PT. SCM di Routa. Kawasan hutan belantara yang kelihatan masih "perawan" itu, diklaim sebagai tanah adat karena konon nenek moyang mereka dahulu pernah berladang di sana atau setidak-tidaknya bermukim untuk sementara waktu. ${ }^{1}$

Penelitian ini menunjukkan adanya perubahan tujuan, orientasi dan prioritas utama perladangan berpindah dari padi ladang ke tanah ladang. Upaya untuk memperoleh padi ladang tidak lagi menjadi isu sentral dalam praktek perladangan berpindah, sebaliknya tanah ladanglah yang menjadi isu sentral perladangan berpindah di Routa saat ini. Hal ini berbeda dengan kajian-kajian sebelumnya yang menempatkan padi ladang sebagai tujuan, orientasi dan prioritas utama perladangan berpindah (Conklin 1961, Seavoy 1973, Rambo 1980 dan 1983, Rosler 1997, Tawulo 1998, Cairns dan Garrity 1999, Adijaya 2000 dan Noordwijk dkk 2008). Artikel ini bertujuan untuk mengeksplorasi strategistretegi yang ditempuh peladang berpindah atau anak keturunan peladang berpindah di Routa dalam rangka menguatkan klaim hak atas tanah bekas areal perladangan berpindah dimasa lalu.

\section{Metode Penelitian}

Penelitian dengan pendekatan kualitatif ini dilaksanakan di Routa, Konawe, Sulawesi Tenggara selama kurun waktu enam bulan antara tahun 2018 dan 2019, dengan pertimbangan bahwa di daerah ini sebagaimana temuan penelitian saya sebelumnya (Adijaya 2012) telah berkembang fenomena baru dimana tanah-tanah bekas areal perladangan di masa lalu kembali dibuka oleh anak keturunan peladang berpindah saat

lokua (areal tempat berburu), aarano atau pinokotei (rawa atau bagian batang sungai tempat menangkap ikan), waworaha (areal tanaman jangka panjang) dan pombahora (kintal yang ditinggalkan) (Tarimana 1989:90). 
ini dengan tujuan untuk menguatkan klaim hak atas tanahnya.

Mereka yang berpartisipasi dalam penelitian ini mencakup mantan camat Routa, mantan kepala desa di Routa, mantan petugas kehutanan di Routa serta petani peladang berpindah di Routa.

\begin{tabular}{|l|l|l|l|l|}
\hline \multicolumn{5}{|l|}{ Tabel 1. Informan } \\
\hline No. & Nama & Usia & Pekerjaan & Domisili \\
\hline 1. & Sukman Unggahi & 80 & Petani/Mantan Kades & Walandawe \\
\hline 2. & Taksir & 50 & $\begin{array}{l}\text { Petani/Mantan Kades/Pengusaha } \\
\text { Kayu }\end{array}$ & Lalomerui \\
\hline 3. & Nusa & 55 & PNS/Mantan Kades/Pengusaha Kayu & Routa/Unaaha \\
\hline 4. & Harpan & 23 & Petani/Mahasiswa & Mopute Baru \\
\hline 5. & Tasrim & 50 & Petani/Mantan Kades & Lalomerui \\
\hline 6. & Husaini & 45 & Petani/Mantan Kades & Walandawe \\
\hline 7. & Lamara & 50 & Petani & Routa \\
\hline 8. & Rasak & 48 & Petani & Routa \\
\hline 9. & Usman & 35 & Petani & Tundundete \\
\hline 10. & Sainuddin & 75 & Petani & Walandawe \\
\hline 11. & Basrin & 65 & Petani & Routa \\
\hline 12. & Basir & 62 & Pensiunan PNS Kehutanan & Kendari \\
\hline 13. & Tajuddin & 65 & Pensiunan PNS Kehutanan & Unaaha \\
\hline 14. & Abu Haseng & 65 & Mantan Camat Routa & Unaaha \\
\hline
\end{tabular}

Pengumpulan data dilakukan dengan mengombinasikan antara wawancara dan observasi. Topik-topik wawancara meliputi realitas ekonomi, sosial dan politik yang mendorong terjadinya perubahan tujuan; orientasi dan prioritas utama peladang berpindah dari tanah ladang ke tanah lading; dinamika relasi ekonomi, sosial dan politik antara peladang berpindah dengan para pihak di Routa; tujuan-tujuan baik eksplisit maupun implisit yang ingin dicapai oleh peladang berpindah dari perubahan tujuan, orientasi dan prioritas utama perladangan berpindah; proses, struktur dan komposisi kepimilikan tanah di Routa; pandangan-pandangan peladang berpindah terhadap kehadiran pengusaha kayu, pengusaha pertambangan, pengusaha perkebunan, migran dan orang kaya di Routa; pandangan-pandangan peladang berpindah terhadap praktek penguasaan tanah-tanah di Routa; respon atau tindakan peladang berpindah atas kehadiran pengusaha kayu, pengusaha pertambangan, pengusaha perkebunan, migran dan orang kaya di Routa; respon atau tindakan peladang berpindah atas praktek penguasaan tanahtanah di Routa, dan lain-lain. Sementara observasi dilakukan dengan mengamati kondisi hutan dan kawasan hutan dalam lokasi izin pengusahaan kayu, lokasi izin perkebunan sawit, lokasi izin pertambangan serta hutan dan kawasan hutan tak berizin; praktek atau aktifitas lapangan pengusahaan kayu, pengusahaan perkebunan sawit, pengusahaan pertambangan; tanah-tanah yang dikuasai para migran; praktek perladangan berpindah, dan; pengusahaan tanah-tanah bekas perladangan berpindah.

Analisa data dilakukan mulai dari awal hingga akhir penelitian atau semenjak diperolehnya data di lapangan (Endraswara 2003:215). Data yang sudah terhimpun melalui 
observasi dan wawancara diklasifikasikan

menurut jenisnya dan dideskripsi secara

holistik-integratif.

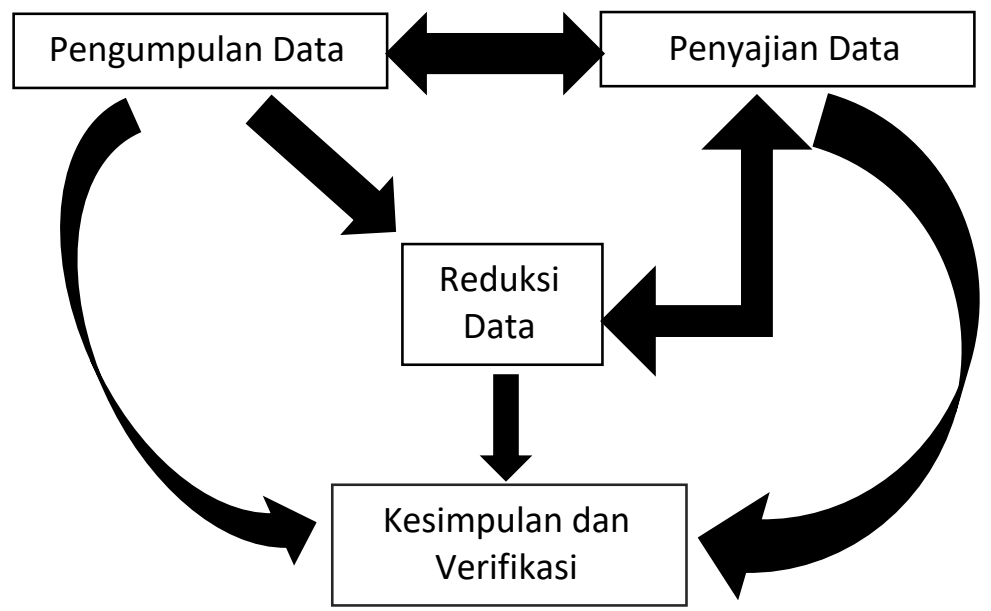

Bagan 1. Komponen Analisis Data Model Interaktif

(Matthew B. Milles \& Michael Huberman 1992; Salim 2006)

Etika yang menjadi pedoman berlaku (code of conduct) peneliti selama berada di lapangan dan penulisan laporan penelitian ini, adalah dengan 1) peneliti menaati norma umum yang berlaku di lokasi penelitian; 2) menjunjung tinggi hak-hak informan terkait maksud, tujuan dan manfaat penelitian, kesediaan mereka untuk terlibat (informed consent) dan untuk direkam saat wawancara berlangsung; menjaga kerahasiaan informasi (confidentiality) dan sumber informasi (anonymous).

\section{Routa dan Bekas Ladang Berpindah}

Hamparan hutan belantara Routa yang luas dan rimbun menghijau, jika dilihat selayang pandang akan nampak seperti layaknya kawasan hutan yang sama sekali belum pernah dijamah sebelumnya oleh manusia. Namun tatkala memasuki kawasan hutan tersebut, kita akan menemukan pemandangan dan kesan yang sama sekali berbeda bahwa ternyata daerah ini telah pernah dijamah oleh manusia-salah satunya melalui aktifitas perladangan berpindah. Hal tersebut dapat dilihat dari adanya bekas-bekas tunggak pohon yang menglapuk sisa penebangan beberapa tahun lampau. Kesan ini pula diperkuat dengan kisah yang diceritakan oleh penduduk setempat mengenai kehidupan orang tua mereka dimasa lalu yang terkenal sebagai peladang ulung di daerah Routa dan meninggalkan jejak bekas areal perladangan berpindah yang tersebar di seantero Routa yang saat ini telah menghutan kembali seperti sediakala.

Sejumlah bekas areal perladangan di masa lalu dimaksud, antara lain, adalah Batubara, Laroawu, Pombole'a Onohu, O'ou, Pombala'a Odopi, Angkeu, Bininti, Puntiko (telah masuk wilayah Sulawesi Selatan), Lerea, Pambada, Heo Epe, Tokaluku, Sampalawa, Walandawe (Wiwirano Motu'o), Leperi, Tetemondoe, Lingato, Tapuwuri, Tetedopi, Hiuka, Laeu, Lawali, Asera Tua, Mandawa, Kuia, Pondoa, Watupali, Mopute, Po'ona, Dambata, Epe Pu'u, Tetenggowuna, Tundundete dan Mosiku.

Bekas areal perladangan berpindah di daerah Bininti diperkirakan seluas 2000 hektar, di daerah Mopute seluas 4.000 hektar dan di daerah Tundundete diperkirakan seluas 2000 hektar. Kontur geografis di daerahdaerah ini secara umum adalah landai khususnya di daerah Bininti, sedangkan di 
daerah Mopute dan Tundundete terdiri dari dataran yang landai yang diselingi dengan bukit-bukit kecil hingga daerah pegunungan dengan kemiringan antara 15 persen hingga 30 persen. Jika diperhatikan secara seksama, maka daerah-daerah bekas areal perladangan berpindah di masa lalu tersebut telah menghutan kembali dan hanya sedikit saja tanda yang menunjukkan sebagai bekas areal perladangan berpindah. Di antara tanda tersebut adalah kerapatan pepohonannya yang tidak sama dengan pepohonan pada hutan primer, tegakan pepohonan yang belum begitu besar, masih terdapat tunggak-tunggak bekas penebangan dan pembakaran, batangbatang pepohonan yang sudah membusuk, serta kadangkala terdapat pula beberapa tanaman tumbuh, seperti kelapa, mangga, langsat dan durian di dalamnya.

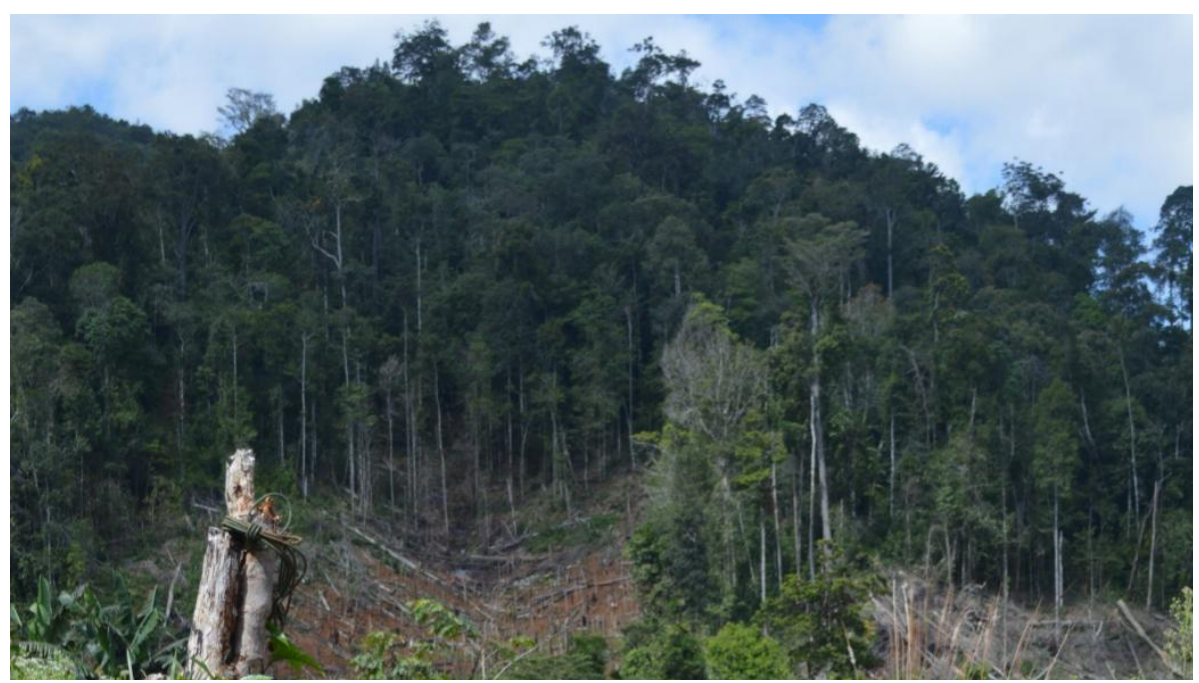

Gambar 1. Pembukaan bekas areal perladangan berpindah di Bininti, 2018.

Bekas areal perladangan berpindah di daerah Bininti kembali dibuka sejak tahun 2010 oleh penduduk yang berasal dari Desa Routa. Pada tahun pertama, lahan yang dibuka diperkirakan seluas 100 hektar, dan penduduk terus melakukan perluasan pada tahun-tahun berikutnya hingga saat ini. Pada awalnya penduduk yang membuka lahan bekas areal perladangan di daerah Bininti adalah anak keturunan dari peladang-peladang di masa lalu (lihat Gambar 1 di atas).

Bekas areal perladangan berpindah di daerah Mopute kembali dibuka oleh anak keturunan peladang berpindah yang berasal dari Mopute Lama pada tahun 2018 yang dipimpin oleh Yen Latorumo. Mereka mengaku sebagai pewaris sah atas tanah bekas areal perladangan berpindah orang tua mereka di masa lalu. Klaim ini kembali dihidupkan ketika kegiatan PT. SCM di lapangan mulai nampak, khususnya dengan terbukanya jalan akses tambang, mobilisasi tenaga kerja dan kegiatan eksplorasi. Oleh karena itu, sejumlah pihak menduga bahwa kembalinya Orang Mopute Lama ke Mopute Baru lebih didorong oleh keinginan untuk mendapatkan kompensasi berupa ganti rugi tanah dari perusahaan. Mereka pada dasarnya tidak seperti peladang berpindah yang kembali ke daerah Bininti, Walandawe dan Tetenggowuna yang memang berniat untuk berladang dan menanam lada sembari menguasai tanah bekas areal perladangan orang tua mereka.

Klaim yang disampaikan oleh anak keturunan orang Mopute mengenai status tanah areal bekas perladangan berpindah di Mopute Baru berbeda dengan yang disampaikan oleh Sukman Unggahi-salah saorang tetua kampung orang Routa. Menurut 
anak keturunan orang Mopute, mereka adalah penduduk asli di daerah Mopute Baru dan tanah yang mereka klaim saat ini adalah bekas areal perladangan berpindah orang tua mereka.

Sementara itu Sukman Unggahi mengatakan bahwa daerah yang dinamakan sebagai Mopute Baru saat itu tidak berpenghuni dan merupakan satu kesatuan dengan daerah Routa yang meliputi Daerah Watulawu di Barat hingga daerah Tundundete di Timur, dimana Mopute Baru sesungguhnya adalah bahagian dari daerah Tundundete. Daerah itu kemudian lebih dikenal sebagai daerah Mopute Baru karena suatu peristiwa Tahun 1953 ketika pasukan DI/TII menang perang di daerah Mopute Lama melawan pasukan TNI yang berbasis di Asera. Ketika itu pasukan DI/TII membawa seluruh penduduk Mopute Lama ke daerah Mopute Baru dengan status sebagai tawanan. Ketika bermukim di daerah Mopute Baru itulah dengan status sebagai tawanan, orang tua mereka membuka areal perladangan berpindah disana. Pada tahun 1957, pasukan TNI kembali terlibat perang dengan pasukan DI/TII di Mopute Baru dan berhasil menumpas pemberontakan DI/TII disana. Setelah TNI menang dalam peperangan, maka seluruh penduduk di Mopute Baru dikembalikan ke kampung semula, yaitu di Mopute Lama di Asera. Nama Mopute Baru di daerah Tundundete diambil dari nama Mopute Lama dengan mengacu pada asal kampung penduduk yang ditawan.

Pernyataan yang berbeda tersebut di atas memerlukan penelusuran lebih lanjut mengenai kebenaran klaim masing-masing pihak. Namun demikian, jikapun hal itu benar bahwa orang Mopute saat itu berladang di daerah Mopute Baru dengan status sebagai tawanan perang, fakta menunjukkan bahwa mereka pernah berladang disana adalah sesuatu yang tak terbantahkan. Hal ini sebagaimana diakui oleh masyarakat di daerah Routa dan sekitarnya yang menyatakan bahwa benar orang tua mereka pernah berladang disana. Oleh karena itu, jika kemudian anak keturunan peladang berpindah di daerah Mopute Baru mengklaim daerah tersebut sebagai bekas areal perladangan berpindah orang tua mereka di masa lalu adalah benar adanya.

\section{Strategi Mempertahankan Lahan}

Berbagai situasi yang terjadi sebagaimana yang dijelaskan di atas membuat anak keturunan peladang berpindah di Routa melakukan beragam strategi untuk mempertahankan penguasaan lahan. Hal ini meliputi: membuka kembali bekas areal perladangan berpindah, menanam tanaman pohon komersil (cashcrop), membuat pagar pembatas, dan mengusahakan bukti hak atas tanah, sebagaimana akan disajikan berikut ini.

\section{Membuka Kembali}

Beberapa bekas areal perladangan berpindah di masa lalu di atas kembali dibuka dan dikuasai oleh penduduk lokal di Routa. Pembukaan bekas areal perladangan berpindah di masa lalu ini-baik yang dilakukan secara bersamasama ataupun sendiri-sendiri-ditujukan untuk menyegarkan dan menegaskan kembali klaim hak kepemilikan atas tanah-tanah tersebut.

Langkah ini dilakukan terkait dengan fenomena penyerobotan tanah-tanah bekas areal perladangan berpindah oleh sejumlah pihak yang kian marak akhir-akhir ini. Di antara bekas areal perladangan berpindah dimasa lalu yang dibuka dan dikuasai bersama-sama secara serentak adalah di daerah Bininti, Mopute dan Tundundete. Sementara bekas areal perladangan berpindah lainnya, seperti di daerah Walandawe, Tetenggowuna dan Lalomerui dibuka dan dikuasai atas inisiatif sendiri-sendiri.

Bekas areal perladangan berpindah di daerah Tundundete mulai dibuka pada tahun 2018 atau bersamaan dengan kembalinya penduduk Mopute Lama ke daerah Mopute 
Baru. Secara geografis, daerah Tundundete dan Mopute Baru memang berbatasan langsung, sehingga kembalinya penduduk dari Pondoa ke Tundundete banyak didorong oleh kembalinya penduduk Mopute Lama ke daerah Mopute Baru. Penduduk yang saat ini kembali membuka ladang di daerah Tundundete berasal dari Desa Pondoa, Kecamatan Wiwirano, Kabupaten Konawe Utara. Secara geografis, Tundundete dan Pondoa berbatasan langsung dan hanya dipisahkan oleh Sungai Lalindu. Dahulu kedua daerah ini secara administratif adalah satu dan menjadi terpisah ketika pemekaran Kabupaten Konawe pada tahun 2007. Kini, daerah Pondoa masuk dalam wilayah Kabupaten Konawe Utara, sementara daerah Tundundete masuk dalam wilayah Kabupaten Konawe.

Jika merujuk pada penggambaran di atas, maka dalam konteks Routa saat ini-dan dalam konteks yang lebih luas dimana terdapat bekas areal perladangan berpindah di masa lalu-dasar ini tidak lagi cukup efektif dijadikan sebagai pijakan klaim hak atas tanah. Hal ini didasarkan pada kenyataan bahwa banyak bekas areal perladangan berpindah di masa lalu yang telah diambil atau diserobot oleh pihak lain tanpa sepengetahuan dan persetujuan anak keturunan peladang berpindah. Sejumlah contoh antara lain bekas areal perladangan berpindah di daerah Watulawu, Puuwiwirano, Tanggola dan Bininti.

Oleh karena itu, kembalinya anak keturunan peladang berpindah di daerah Bininti, Mopute, Tundundete Walandawe dan Tetenggowuna mernjadi strategi untuk mencegah upaya penyerobotan tanah-tanah bekas areal perladangan berpindah tersebut oleh pihak lain. Strategi yang ditempuh anak keturunan peladang berpindah di masa lalu ini cukup efektif, paling tidak jika dilihat dalam dua hal yaitu: 1) bahwa setelah kembalinya mereka ke tanah-tanah bekas areal perladangan berpindah di masa lalu tersebut, maka saat ini praktis tidak ada lagi pihak lain yang mencoba menyerobot atau memasuki kawasan ini tanpa sepengetahuan atau persetujuan mereka, dan; 2) bahwa pihakpihak lain yang selama ini menganggap kawasan hutan tersebut sebagai lahan tak bertuan, kini memahami bahwa ternyata tanah-tanah tersebut adalah milik anak keturunan peladang berpindah dari Bininti, Walandawe, Tetenggowuna, Mopute dan Tundundete.

\section{Menanam Tanaman Pohon Komersial}

Selain membuka kembali bekas areal perladangan berpindah orang tua mereka di masa lalu, strategi lainnya yang ditempuh oleh anak keturunan peladang berpindah di Routa dalam rangka mempertahankan tanah bekas areal perladangan berpindah adalah dengan menanam tanaman tumbuh.

Pada kenyataannya, tanah-tanah bekas areal perladangan berpindah tidak lagi ditinggalkan begitu saja oleh peladang berpindah. Pengamatan di lapangan menunjukkan bahwa areal bekas perladangan berpindah sudah ditanami tanaman, seperti jambu mete dan kakao pada beberapa bagiannya dengan jumlah sedikit dan tidak dirawat dengan baik. Sedang pada bagian areal yang lainnya sudah ditumbuhi tanaman rambat dan kayu-kayuan. Bekas areal perladangan berpindah ini nampak tidak pernah dibersihkan sehingga mulai menghutan kembali. Bekas areal perladangan berpindah semacam ini cukup banyak ditemukan di daerah Walandawe, Lalomerui, dan Tetenggowuna (lihat Gambar 2 di bawah ini). 


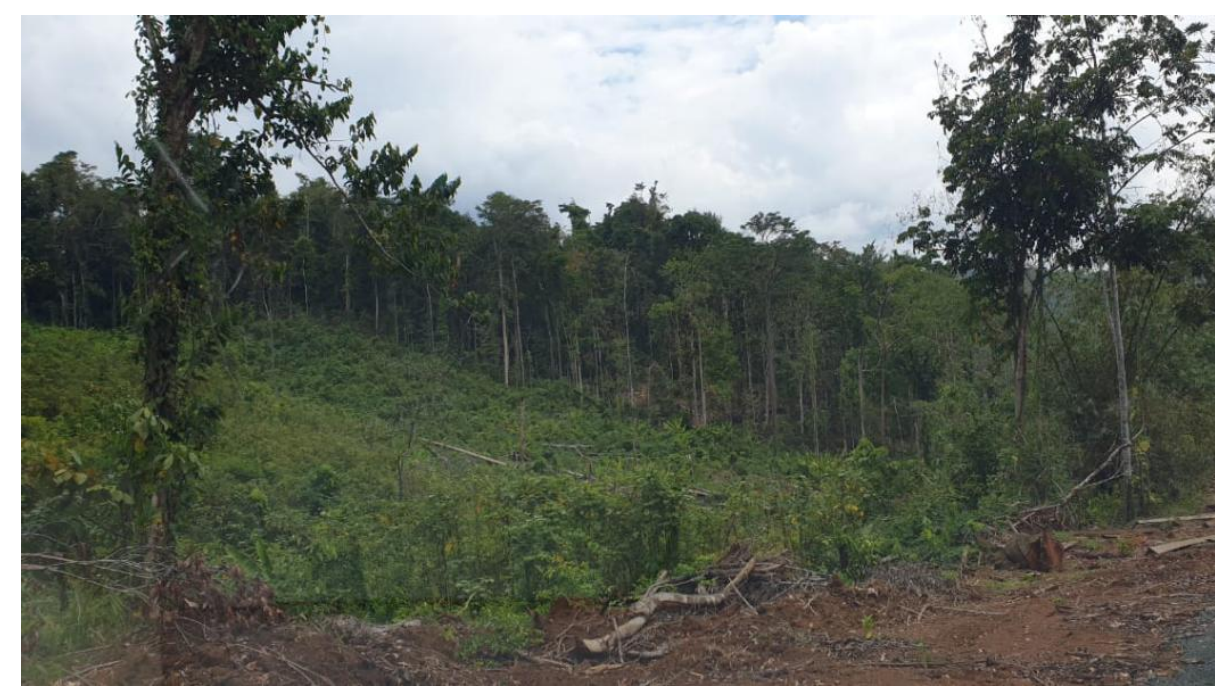

Gambar 2. Bekas areal perladangan berpindah di Tetenggowuna, 2018

Selain itu, ada pula bekas areal perladangan berpindah yang sudah ditancapkan tiang penyangga lada walaupun tanaman ladanya belum ada. Sejumlah informan mengatakan bahwa penanaman lada membutuhkan biaya yang tidak sedikit, sehingga harus dikerjakan secara bertahap. Biasanya kebun yang sudah ditancapkan tiang penyangga lada segera ditanami paling lambat dalam satu dua tahun mendatang. Bekas areal perladangan berpindah seperti ini banyak ditemukan di daerah Walandawe, Tetenggowuna, Lalomerui dan juga sebahagian Bininti dan Routa.

Menanam tanaman jangka panjang atau lada merupakan suatu strategi peladang berpindah di Routa dalam rangka menegaskan klaim hak atas suatu bidang tanah. Tanamantanaman tumbuh yang ada mengindikasikan bahwa tanah tersebut sudah dikuasai atau dimiliki oleh seseorang, sehingga tidak memungkinkan orang lain untuk mengklaim sebagai pihak yang berhak atas bidang tanah yang sama.

Strategi yang ditempuh oleh peladang berpindah di Routa ini tidak terlepas dari fenomena seringnya terjadi sengketa atas tanah antar sesama penduduk lokal maupun dengan pendatang terhadap tanah-tanah berkas areal perladangan yang tidak ditanami dengan tanaman-tanaman tertentu, seperti jambu mete, kakao atau lada. Potensi sengketa ini menajam jika areal perladangan berpindah tersebut tidak ditanami dan kembali menghutan seperti sediakala.

Oleh karena itu, strategi menanami tanaman-tanaman tertentu pada tanah bekas ladang berpindah cukup berhasil, jika dilihat dalam dua hal: pertama, suatu bidang tanah diakui oleh penduduk di Routa secara tegas sebagai dikuasai atau telah dimiliki oleh seseorang; kedua, tidak pernah lagi ada sengketa sesama penduduk lokal maupun dengan migran atau pencaplokan tanah-tanah yang sudah ditanami atau dipenuhi tanaman tertentu dari penduduk lainnya. Dengan kata lain, tingkat kepastian klaim kepemilikan atas suatu bidang tanah menjadi semakin kuat.

Bagi peladang berpindah di Routa, menanam tanaman tumbuh pada bekas areal perladangan berpindah dengan demikian tidak semata dimaksudkan untuk memperoleh hasil dari tanaman-tanaman tumbuh itu, tetapi dan terutama sekali lebih ditujukan sebagai penegasan kepenguasaan atas tanah tersebut. Karena itulah dalam kenyataannya seringkali ditemukan tanaman-tanaman tumbuh berupa pohon mangga, langsat, sagu, durian, jambu mete dan tanaman pohon lainnya yang 
jumlahnya hanya satu dua pohon saja dan nampak ditanam serampangan tak beraturan.

\section{Membuat Pembatas}

Membuat pembatas adalah strategi lainnya bagi peladang berpindah untuk mengamankan tanahnya dari klaim pihak lain. Pembatas yang digunakan oleh peladang berpindah meliputi pagar kayu, pagar hidup maupun berupa galian parit. Pada areal perladangan yang baru saja dibuka, pagar yang umumnya dibuat adalah pagar kayu berupa batang dan cabang-cabang kayu yang dipasang horisontal dari sisa-sisa pembakaran yang tidak hangus. Di masa lalu pagar semacam ini hanya semata-mata dimaksudkan untuk menghalau babi hutan dan anoa yang biasanya masuk merusak tanaman padi ladang dan tanaman-tanaman lainnya. Sementara itu, untuk dapat mengetahui batasbatas areal perladangan masing-masing yang digunakan biasanya adalah batas alam, seperti kali-kali kecil atau punggung bukit dengan penanda tertentu, seperti pohon kayu tertentu yang tidak ditebang atau tunggak kayu. Penanda semacam itu sudah cukup efektif bagi kalangan peladang berpindah di masa lalu untuk digunakan sebagai pembatas tanah masing-masing peladang.

Seiring dengan terjadinya perubahan pola berladang yang lebih cenderung dilakukan secara sendiri-sendiri, maka pembuatan pagar sebagaimana dimaksud di atas yang sebelumnya hanya untuk mengahalau binatang pengganggu tanaman, juga sekaligus berfungsi menjadi batas-batas tanah peladang yang bersangkutan. Pagar semacam ini sifatnya temporal saja, hanya pada saat pembukaan areal perladangan berpindah dan seiring dengan selesainya masa panen, maka pagar tersebut akan dibiarkan begitu saja, hingga membusuk tak meninggalkan bekas sama sekali. Fungsi pagar kayu semacam ini sebagai pembatas kemudian akan digantikan dengan pembatas lainnya yang lebih permanen antara lain pagar tancap yang lebih kokoh atau pula berupa pagar hidup.

Ketika tanah bekas areal perladangan berpindah tersebut hendak dijadikan kebun lada, maka biasanya peladang akan membangun pagar yang lebih permanen, kuat dan tahan lama. Jenis pagar yang dipilih adalah pagar tancap dari jenis kayu-kayu keras yang dibelah empat seperti layaknya tiang penyangga lada. Setelah ditancap, tiang-tiang kayu pagar ini kemudian dirangkai dengan kawat atau rotan agar nampak lebih kokoh dan tidak rubuh. Kendati fungsinya hanya sebagai pagar, tetapi karena bangunannya yang lebih kuat dan tahan lama dibandingkan pagar ladang biasa, maka pagar semacam ini sekaligus pula secara langsung dapat menjadi penegas batas-batas tanah kebun seseorang dengan orang lainnya. Pagar tancap seperti ini cukup banyak ditemukan di Routa, termasuk itu pula di kalangan penduduk pada umumny.

Jenis pembatas lainnya yang digunakan oleh peladang berpindah adalah pagar hidup. Dahulu jenis tanaman yang digunakan untuk membangun pagar hidup adalah pohon maja. Namun sekarang jenis tanaman ini sudah langka ditemukan dan masyarakat sendiri juga sudah jarang menggunakannya. Kini lebih banyak orang yang menggunakan pohon gamal sebagai pagar hidup yang dinilai lebih mudah tumbuh dan mudah dirapihkan.

Selain pagar hidup ini, ada pula penduduk yang membangun parit pembatas. Parit yang dibuat biasanya sedalam setengah meter hingga satu meter dan lebar setengah meter, yang kadang kala dirangkaikan dengan pembagunan pagar kayu dan/atau pagar hidup. Sering kali pula ditemukan sejumlah bidang tanah yang sudah ditumbuhi gulma dan alang-alang, nampak kelihatan seperti tanah terlantar yang tak berpemilik karena tiadanya penanda seperti pagar tancap kayu atau pagar hidup. Namun ternyata pada tanah-tanah seperti itu terdapat parit pembatas hanya saja 
tidak kelihatan karena tertutup gulma atau alang-alang.

Pembuatan parit pembatas tidak begitu menjadi pilihan bagi peladang di Routa untuk menegaskan batas-batas tanahnya. Hal tersebut bukan karena fungsinya yang tidak efektif, tetapi karena biaya dan tenaga yang dibutuhkan untuk membuatnya dianggap terlalu besar jika dibandingkan dengan padar hidup. Karena itulah hanya sedikit saja peladang berpindah yang memilih membuat parit pembatas.

Strategi membuat pembatas cukup berhasil jika dilihat dalam dua hal. Pertama, bahwa tanah-tanah yang telah dipagari secara langsung semakin mengokohkan klaim hak hak atas suatu bidang tanah oleh yang bersangkutan, ada atau tidak ada tanaman tumbuh di dalamnya. Kedua, dengan adanya pembatas maka batas-batas tanah antar orang-perorang menjadi sangat jelas dan tegas, sehingga tidak ada lagi kemungkinan terjadinya sengketa batas-batas tanah.

\section{Mengusahakan Bukti Hak Atas Tanah}

Membuka kembali bekas areal perladangan berpindah, lalu menanaminya dengan tanaman tumbuh dan disertai dengan membuat pembatas baik berupa pagar tancap, pagar hidup maupun parit pembatas seluruhnya adalah strategi yang memberikan bukti-bukti yang bersifat fisik atas penguasaan suatu bidang tanah, namun klaim semacam ini tidak memiliki kekuatan hukum. Berkenaan dengan hal tersebut, legalisasi hak atas lahan menguatkan klaim tersebut.

Dalam Peraturan Pemerintah Nomor 24 Tahun 1997 tentang Pendaftaran Tanah (selanjutnya disebut PP Pendaftaran Tanah) menyebutkan bahwa untuk memberikan kepastian dan perlindungan hukum kepada pemegang hak yang bersangkutan diberikan sertifikat hak atas tanah. Dalam PP Pendaftaran Tanah ini juga dinyatakan bahwa sertifikat hak atas tanah merupakan surat tanda bukti hak yang berlaku sebagai alat pembuktian yang kuat mengenai data fisik dan data yuridis yang termuat di dalamnya, sepanjang data fisik dan data yuridis tersebut sesuai dengan data yang ada dalam surat ukur dan buku tanah hak yang bersangkutan.

Berdasarkan data Tahun 2019, luas tanah di Routa yang sudah disertifikatkan adalah 1.200 hektar (10.182,28 hektar) dengan rincian sebagai berikut:

\begin{tabular}{|l|l|c|}
\hline \multicolumn{2}{|c|}{ Tabel 2. } \\
\hline Ko. & Desa/Kelurahan & Luas (Ha) \\
\hline 1. & Parudongka & 210 \\
\hline 2. & Tirawonua & 190 \\
\hline 3. & Routa & 110 \\
\hline 4. & Walandawe & 182 \\
\hline 5. & Puuwiwirano & 210 \\
\hline 6. & Tanggola & 178 \\
\hline 7. & Lalomerui & 210 \\
\hline & Total & $\mathbf{1 2 0 0}$ \\
\hline
\end{tabular}

Sumber: Badan Pertanahan Nasional Kab. Konawe, 2019.

Data di atas menunjukkan bahwa dari total luas APL (Areal Penggunaan Lain) di Kecamatan Routa, yakni $10.182,28$ ha (21, $79 \%)$ yang sudah disertifikatkan hanya seluas
1.200 ha $(21,79$ persen) sehingga masih ada $8.982,28$ hektar $(88,21 \%)$ tanah yang belum disertifikatkan. 
Sementara itu hasil pendataan langsung terhadap 282 petak tanah milik sejumlah penduduk di Routa yang tersebar di enam desa dan satu kelurahan diperoleh persentase alas hak kepemilikan sebagai berikut:

\begin{tabular}{|l|l|c|c|}
\hline \multicolumn{4}{|c|}{ Tabel 3. } \\
\hline \multicolumn{4}{|c|}{ Komposisi Luas Tanah Menurut Desa/Kelurahan Yang Sudah Disertifikatkan } \\
\hline No. & $\begin{array}{l}\text { Jenis Alas Hak/Tanda } \\
\text { Administrasi }\end{array}$ & $\begin{array}{c}\text { Jumlah Petak } \\
\text { Tanah }\end{array}$ & Persentase (\%) \\
\hline 1. & Sertifikat Hak Milik/SHM & 45 & 15,96 \\
\hline 2. & Surat Keterangan Tanah/SKT & 66 & 23,40 \\
\hline 3. & Bukti Pembayaran Pajak/PBB & 9 & 3,19 \\
\hline 4. & Tanpa Tanda Administrasi & 162 & 57,45 \\
\hline & Total & 282 & 100 \\
\hline
\end{tabular}

Sumber: Hasil Pendataan, 2019.

Jika angka pada Tabel 3 tersebut di atas berlaku secara konsisten dan mencerminkan keadaan yang sesungguhnya, berarti baru sebagian kecil saja tanah-tanah yang ada di Routa saat ini-baik yang dikuasai oleh pendatang maupun penduduk lokalyang sudah memiliki alas hak yang benar yaitu berupa sertifikat hak milik (SHM), yakni: 45 kapling tanah (11,76 hektar). Selebihnya 237 kapling tanah (302,9 hektar) dianggap belum memiliki legalitas.

Strategi ini cukup berhasil jika dilihat dalam dua hal yaitu: pertama, kendati SKT (Surat Keterangan Tanah) bukan sebagai alas hak yang sah atas tanah, namun hal tersebut menjadi bukti administrasi kepemilikan tanah bagi penduduk yang diakui oleh pemerintah desa, sehingga keberadaannya tetap dianggap penting paling tidak sebagai pengakuan kepemilikan di tingkat desa. Sejumlah masyarakat pula bahkan menyamakan kedudukan SHM dan SKT dan menganggap keduanya sebagai alas hak yang sah atas tanah. Kedua, dengan adanya SHM dan SKT, maka harga jual tanah menjadi lebih tinggi dibandingkan dengan tanah yang tidak memiliki SHM atau SKT. Tanah-tanah di Routa yang tidak memiliki alas hak sama sekali dijual Rp5.000.000,- per hektar, yang sudah memiliki SKT dijual Rp.10.000.000,- per hektar, dan tanah dengan SHM bisa laku hingga Rp.40.000.000,- per hektar. Ini menunjukkan bahwa surat alas hak itu penting tidak saja dalam kaitan dengan harga tanah, tapi terutama karena legalitas dari tanah itu sendiri. Artinya, legalitas berpengaruh signifikan terhadap tinggi-rendahnya harga tanah di Routa.

Sejumlah kendala yang seringkali dihadapi peladang berpindah dalam rangka pelaksanaan strategi-strategi tersebut di atas adalah: keterbatasan modal yang dimiliki untuk menanam tanaman tumbuh terutama lada, membuat pagar tancap dan parit pembatas. Sedangkan untuk pembangunan pagar hidup relatif mudah dilakukan dan cenderung tanpa kendala karena peladang bisa mengerjakannya secara sambilan dan bahan baku yakni pohon gamal atau maja banyak terdapat di Routa. Sementara itu dalam rangka mengusahakan bukti hak atas tanah, kendala yang seringkali dihadapi peladang selain biaya yang mahal juga layanan birokrasi yang berbelit-belit dan waktunya yang lama.

\section{Kesimpulan dan Rekomendasi}

Tanah-tanah bekas areal perladangan berpindah dimasa lalu yang memiliki beragam istilah, yakni orawu, anahoma, laliwata dan osambu, yang sejatinya adalah milik anak 
keturunan peladang berpindah di Routa, saat ini sudah banyak diserobot dan dikuasai oleh pihak-pihak lain. Berkenaan dengan situasi tersebut, maka anak keturunan peladang berpindah di Routa mengembangka sejumlah strategi dalam rangka menguatkan/menyegarkan kembali klaim hak atas tanah bekas areal perladangan berpindah orang tua mereka dimasa lalu. Strategi-strategi tersebut adalah: 1) membuka kembali bekas areal perladangan berpindah orang tua mereka dimasa lalu; 2) penanaman tanaman tumbuh; 3) pembuatan pembatas, dan; 4) melegalkan hak atas tanah. Strategi-strategi ini terbukti cukup berhasil dalam mengatasi penyerobotan tanah-tanah bekas areal perladangan berpindah serta menjadi basis ekonomi baru bagi peladang berpindah berupa tanah dan kebun.

Beragam strategi adaptasi sebagaimana temuan dalam penelitian ini memperkuat teori Bennet (1976:251), bahwa adaptasi merupakan kapasitas manusia untuk melakukan inovasi, menemukan solusi atas suatu perubahan, mencari hal baru yang belum pernah ada sebelumnya, mempertahankan praktek-praktek lama yang sudah menjadi kebiasaan atau mempermaklumkan hal baru sebagai suatu kewajaran. Individu atau kelompok dapat beradaptasi dengan menemukan solusi baru untuk masalah baru ataupun terhadap masalah yang sudah lama terjadi; atau mungkin beradaptasi dengan hanya belajar hidup dengan situasi yang ada dan tidak mengkhawatirkannya; atau menyesuaikan perilaku lain dengan kenyataan yang ada.

Dalam konteks perladangan berpindah di Routa, peladang berpindah merespon perubahan lingkungan yang terjadi dengan cara memodifikasi tujuan perladangan berpindah dari padi ladang ke tanah ladang. Dengan inovasi tersebut, peladang berpindah tidak saja dapat memenuhi keinginankeinginan mereka untuk menguasai tanah- tanah bekas areal perladangan berpindah di masa lalu, tetapi juga dengan tanah yang nilai dan harganya terus meningkat, mereka sekaligus dapat mengatasi masalah kesulitan keuangan yang seringkali dihadapi oleh peladang berpindah di Routa.

Berkaitan dengan simpulan di atas, pemerintah perlu memberikan pengakuan hak atas tanah pada areal bekas perladangan berpindah saat ini dan mengakui klaim hak kepemilikan atas tanah-tanah bekas areal perladangan berpindah dimasa lalu sepanjang hal tersebut dapat dibuktikan. Berkenaan dengan hal ini, maka pemerintah perlu memprioritaskan sasaran utama kebijakan TORA (Tanah Obyek Reformasi Agraria) kepada tanah-tanah bekas areal perladangan berpindah yang dilakukan oleh penduduk lokal seperti di Routa. Selain itu pemerintah perlu pula melakukan program-program pemberdayaan kepada komunitas peladang berpindah sebagai bagian yang terintegrasi dan simultan dengan pengakuan hak-hak atas tanah peladang berpindah dan perlindungan terhadap praktek perladangan berpindah yang ramah terhadap lingkungan.

\section{Daftar Pustaka}

Adijaya, S. 2000. Monda'u dan Kelestarian Hutan: Suatu Kajian Mengenai Sistem Perladangan pada Masyarakat Tolaki di Desa Pamandati. Skripsi, Fakultas IImu Sosial dan Ilmu Politik, Universitas Haluoleo, Kendari.

Alland Jr., A. 1970. Adaptation in Cultural Evolution: An Approach to Medical Anthropology. New York and London: Columbia University Press.

Bakker, L. 2007. Can We Get Hak Ulayat? Land and Community in Pasir and Nunukan. This paper was presentend at an Indira Project workshop at Universitas Gadjah Mada, 
Yogyakarta, Indonesia, 31 Mei - 3 Juni 2007.

Beckmann, F. B. dan Beckmann, K. B. 2008. Transforming Traditions: Myths and Stereotypes About Traditional Law in a Globalizing World. Paper to be presented at the panel "Law Matters: Mapping Legal Diversity", EASA Conference "Experiencing Diversity and Mutuality", 26-30 Agustus 2008. Ljubljana, Slovenia.

Bennet, J. W. 1969. Northern Plainsmen: Adaptive Strategy and Agrarian Life. New Brunswick: Aldine Transaction.

1976. The Ecological Transition: Cultural Anthropology and Human Adaptation. Washington University: Pergamon Press .

Cairns, M. dan Garrity, D. P. 1999. "Improving Shifting Cultivation in Southeast Asia By Building On Indigenous Fallow Management Strategies", Agroforestry System 47:37-48.

Conklin, C. H. 1961. "The Study of Shifting Cultivation", Current Anthropology, Februari, Vo.2 No.1:27-61.

Hardesty, L. D. 1941. Ecological Anthropology. Toronto: John Willey and Sons.

Harsono, B. 1996. Hukum Agraria Indonesia: Himpunan Peraturan-Peraturan Hukum Tanah. Jakarta: Djambatan.

Lynch, O. J. dan Talbott, K. 1999 Keseimbangan Tindakan: Sistem Pengelolaan Hutan Kerakyatan dan Hukum Negara di Asia dan Pasifik (terjemahan). Jakarta: World Research Institute dan Elsam.
Moran, E. F. 1979. Human Adaptability. North Scituate, Massachusetts: Duxbury Press.

Rambo, A. T. 1980. "Fire and the Energy Efficiency of Swidden Agriculture", Asian Perspectives, XXIII (2): 309-316. 1983. Conceptual Approaches to Human Ecology. Honolulu: East-West Environment and Policy Institute.

Rosler, M. 1997. "Shifting Cultivation in the Ituri Forest: Colonial Intervention, Present Situation, Economic and Ecological Prospects", Civilisations Revue Internationale D'anthropologie et de Sciences Humaines (44:1997) Les Peuples des Forêts Tropicales. Institut de sociologie de l'Université Libre de Bruxelles. 44-61.

Salim, A. 2006. Teori dan Paradigma Penelitian Sosial. Jogyakarta: Tiara Wacana.

Seavoy, E. R. 1973. "The Shading Cycle in Shifting Cultivation", Annals of the Association of American Geographers, Desember, 63(4):522528.

Spradley, J. P. 2007. Metode Etnografi (terjemahan). Jogyakarta: Tiara Wacana.

Steward, J. H. 1976. "The Concept and Method of Cultural Ecology", dalam Steward, J.C. dan Murphy, R. F. (ed.) Evolution and Ecology. Urbana Chicago London: University Of Illinois Press, 43-57.

Suhendar, E. dan Kasim, I. 1996. Tanah Sebagai Komoditas: Kajian Kritis Atas Kebijakan Pertanahan Orde Baru. Jakarta: ELSAM. 
Strategi Peladang Berpindah di Routa Dalam Rangka Menguatkan Klaim Hak Atas...

Taridala, Y. dan Adijaya, S. 2002. Pranata Hutan Rakyat. Jogjakarta: Debut Press.

Tarimana, A. R. 1989. Kebudayaan Tolaki. Jakarta: Balai Pustaka.

Tawulo, A. 1998. Perladangan Berpindah dan Dampaknya Terhadap Kelestarian Hutan. Kendari, Lembaga Penelitian Universitas Haluoleo.

Ter Harr. 2001. Asas-Asas dan Susunan Hukum Adat (terjemahan). Jakarta: PT. Pradnya Paramita.

Van Noordwijk, M., dkk. 2008. Swiddens in Transition: Shifted Perceptions on Shifting Cultivators in Indonesia. Bogor: World Agroforestry Centre. 